\title{
A Redescription of Lutzomyia (Nyssomyia) intermedia (Lutz \& Neiva, 1912), and Resurrection of $L$. neivai (Pinto, 1926) (Diptera, Psychodidae, Phlebotominae)
}

\author{
CB Marcondes ${ }^{+}$ \\ Departamento de Microbiologia e Parasitologia, CCB, UFSC/Campus Trindade, 88040-900 \\ Florianópolis, SC, Brasil
}

\begin{abstract}
Lutzomyia (Nyssomyia) intermedia (Lutz \& Neiva) is redescribed, a neotype is designated, and a very similar species, L. (N.) neivai (Pinto, 1926), is resurrected; the male and the female are redescribed. The two species can be differentiated by differences in the spermathecae, common ducts and number of cibarial horizontal teeth of the females and in the size and proportions of several structures of both sexes. The known geographical distribution of both species is given.
\end{abstract}

Key words: Lutzomyia intermedia - Lutzomyia neivai - geographical distribution - Phlebotominae - taxonomy

Lutzomyia intermedia is a suspected vector of cutaneous leishmaniasis in the states of Rio de Janeiro and São Paulo, Brazil (Rangel et al. 1984, 1990, Gomes 1992). The species was briefly described by Lutz and Neiva (1912), from several insects believed to be this species. Nitzulescu (1930) and Theodor $(1931,1932)$ illustrated the spermathecae and cibarium and Barretto (1946, 1947) studied the taxonomy of several "Phlebotomus intermedius" and considered some of the references as synonyms of other species.

It now appears that $L$. intermedia may represent a species complex. I studied about 750 specimens of $L$. intermedia-like sandflies from Bolivia, Paraguay, two provinces of Argentina and 12 states of Brazil, and showed the existence of two species. Lutz and Neiva (1912), in their original description, referred to Ouro Fino Farm, in Benjamin Constant, State of Minas Gerais. This farm is now located at the municipality of Além Paraíba (JE Silva 1994, pers. commun.). Barretto (1947) considered this locality as the type locality of the species. The types of L. intermedia could not be found in the Oswaldo Cruz Institute collection (SJ Oliveira 1994, pers. commun.). Recently, Nataly Souza, Maurício Villela (Dept. Entomology, Oswaldo Cruz Institute) and I made collections at the type locality to define the species which occurs at this site. Specimens captured there are described here as L. intermedia. The other species is

\footnotetext{
${ }^{+}$CAPES fellow, post-graduation Entomology, UFPR. Fax: 55-48-231.9258. e-mail: cbrisola@mbox1.ufsc.br Received 25 August 1995 Accepted 1 April 1996
}

considered as Lutzomyia neivai (Pinto, 1926), which was previously considered as a synonym of L. intermedia but which is revalidated here. Its male holotype was examined, and a female specimen, also collected at its type-locality (Butantan Institute, São Paulo, SP, Brazil), has spermathecae and ducts visible enough to be identified as belonging to the different species. A female specimen from Bolivia, in better condition, was used here to complete the redescription.

The specimens from Além Paraíba and Bolivia were slide-mounted with NC (Cerqueira 1945), and the specimens from Butantan were slide-mounted with Canada balsam. Some female insects were dissected, the genital fork, ducts and spermathecae separated, following Killick-Kendrick et al. (1994), but staining was done with acid fucsin and the flies were mounted in NC. All measurements are in $\mu \mathrm{m}$. The ranges of some measurements of the examined specimens are given in brackets.

\section{Lutzomyia (Nyssomyia) intermedia (Lutz \& Neiva, 1912)}

Neotype female (code- MGAP-15F): Head: length: 368.6; width: 363.8; minimal distance between eyes: 123.5 ; length of head/ clypeus: 3.08 ; ; palpal formula: 1.4.3.2.5 (P1: 42.78, P2: 132.6, P3: 126.9, P4: 57.12, P5: 148.7); labrum: 311.7; ant. III:207.1; ant. IV: 95.12; ant. V: 95.6; AIII/labrum: 0.67 ; cibarium with eight styletiform, small, equidistant horizontal teeth; 50 small vertical teeth; pigment patch small and round, cibarial arch complete.

Thorax: length of mesonotum: 529.8; wing: length: 1902; maximum width: 594.9, wing sections: $R_{2}(\alpha): 534.6, R_{2+3}(\beta): 263.4, R_{2+3+4}(\gamma)$ : 207.5, $\delta: 307.8, \varepsilon: 688, \pi: 162.1, \mathrm{R}_{5}: 1273$; femorae (first, second and third, respectively): 703.3. 711.7 e 742.3, without spines. 
Abdomen: spermathecae (Fig. 1): 12 subequal rings (9-17); total length: 58.79 (42.3-72.66); length of head: 12.43; one with simple head and other multilobed; width of body: 16.01 (11.7119.84); width of head: 16.01; width of head/ width of body: 1 (0.37-1.29); length of individual duct: 91.78; length of common duct: 46.84; individual duct /common duct: 1.96 (0.56-4.79).

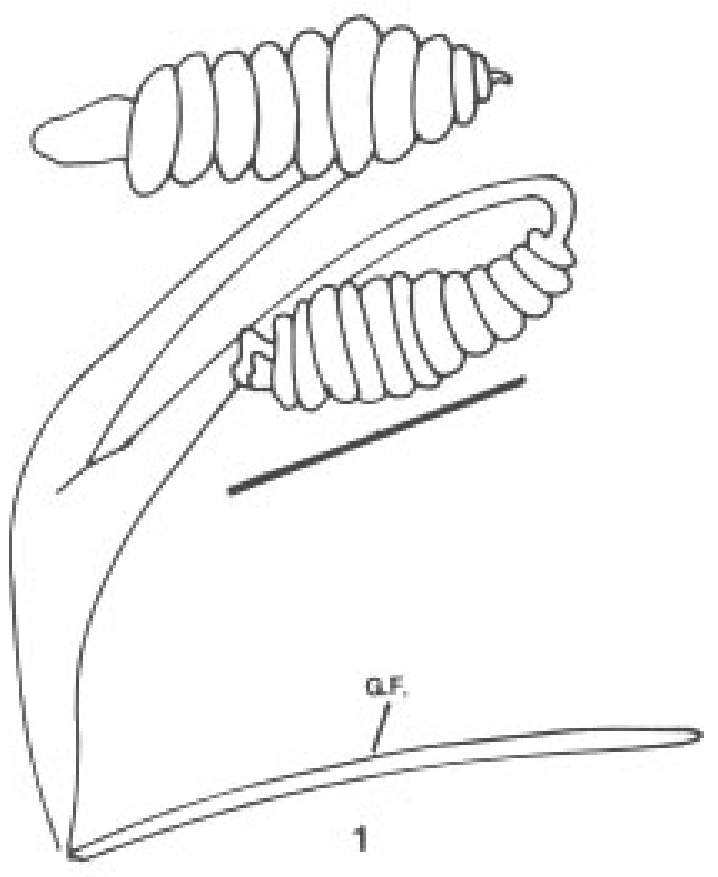

Fig. 1: spermathecae and ducts of Lutzomyia intermedia - neotype, Além Paraíba, Minas Gerais, Brazil (MGAP-15F); G. F.: genital fork.

Male specimen (code- MGAP-22M): Head: length: 330; width: 325.2; palpal formula: 1.4.5.2.3 (P1:32.26; P2: 101.6; P3: 123.3; P4: 44.22; P5: 90.34); labrum: 203.6; ant. III: 219.1; ant. IV: 100.6; ant. V: 103.5; AIII/ labrum: 1.08 .

Thorax: wing: length: 1668, maximum width: 467, $\alpha: 434.2, \beta: 233.5, \gamma: 176.6, \delta: 201.9, \varepsilon: 549.1$, $\pi: 163.1, \mathrm{R}_{5}: 1098$; first femur: 633.8 ; second femur: 625.5.

Abdomen: coxite simple, without tuft of permanent hairs, with some deciduous median hairs (length: 279.8; maximum width: 65.96); style (length: 136.5; maximum width: 32.7 ) with four spines, one terminal and others at 71.94, 71.94 and $106.6 \mu \mathrm{m}$ from the proximal extremity; paramere similar to a hand closed, with second finger pointing posteriorly and slightly dorsally curved, total length: 173; lateral lobe curved, length: 280.8; genital pump: 207.5; filaments: 298.2; filaments/ pump: 1.44; tips of filaments spoon-shaped.
Known geographical distribution: Brasil [Ceará, Pernambuco, Bahia, Espírito Santo, Rio de Janeiro, Minas Gerais (in Lagoa Santa and in several sites localized on the east side of the state), São Paulo (in the east of Serra do Mar and in Pariqüera Açu)].

Type material: the female specimen was collected in Além Paraíba, State of Minas Gerais, on 28-29 March 1995, by CB Marcondes, N Souza and M Vilela, and is designated as the neotype. It was used in the above description and deposited in the collection of Faculdade de Saúde Pública/USP (São Paulo) (DE/FSP-E-10977). The above described male was collected with the female and was deposited in the same collection (DE/FSP-E10975). Other specimens will be deposited at Instituto Oswaldo Cruz (Rio de Janeiro), Centro de Pesquisas René Rachou (Belo Horizonte), Departamento de Medicina Social of UFES (Vitória), Instituto Adolfo Lutz (São Paulo), Instituto Butantan (São Paulo), Instituto Investigaciones Enfermedad Chagas Fatala Chaben (Buenos Aires) and Departamento de Microbiologia e Parasitologia of CCB/UFSC (Florianópolis).

Observations: the cibaria of some specimens have a pair of small teeth, lateral to the eight principal horizontal teeth; the heads of spermathecae (119 specimens) are bilobed (63.9\%), simple $(23.5 \%)$, asymmetrical $(10.1 \%)$ or trilobed $(2.5 \%)$.

\section{Lutzomyia (Nyssomyia) neivai (Pinto, 1926)}

Holotype male: Head: length: 336.8; palpal formula: 1.4.2.5.3 (P1: 41.82, P2: 107.8, P3: 143.6, P4: 52.82, P5: 116.4); labrum: 233.5; ant. III: 250; ant. IV: 113; ant. V: 112.1; Ant. III/ labrum: 1.07.

Thorax: wing: length: 1954; maximum width: 594.9; $\alpha: 538.5 ; \beta: 281.8 ; \gamma: 221 ; \delta: 302 ; \varepsilon: 708.3$; $\alpha / \beta$ : 1.91; second femur: 786.7; third femur: 761.7.

Abdomen: terminalia similar to L. intermedia; coxite (length: 280.8, width: 52.1); style (length: 136.9, width: 35.85 ) with four spines, one terminal and other at 75.28, 75.28 and 107.7 from the proximal extremity; paramere length: 189.5 ; lateral lobe length: 269.2 ; genital pump: 177.8 ; filaments: 311.7 ; filaments/ pump: 1.75 .

Female specimen (code- BOBE-14F): Head: length: 360.9; width: 345.5 ; minimal distance between eyes: 121.6; length of head/ clypeus: 3.12 ; palpal formula: 1.4.2.5.3 (P1: 43.5, P2: 143.4, P3: 182.1, P4: 66.2, 144.1); labrum: 339.7; ant. III: 217.1; ant. IV: 99.18; ant. V: 95.12; AIII/ labrum: 0.64; cibarium with ten styletiform, small, equidistant horizontal teeth; 50 vertical teeth; pigment patch small and round; cibarial arch complete.

Thorax: length of mesonotum: 562.6; wing: length: 2035 ; maximum width: $569.9, \alpha: 538.5, \beta$ : 
538.5, $\gamma: 202.6, \delta: 270.2, \varepsilon: 701.6, \pi: 222.9, \mathrm{R} 5:$ 1354; femorae (first, second and third, respectively): 723.8, 734.4, 770.1, without spines.

Abdomen: spermatheca (Fig. 2): 9 (6-11) subequal rings; total length: 42.3 (30.35-57.6); length of head: 9.56 ; simple head; width of body: 12.19 (8.04-20.08); width of head: 7.65 (4-11.71); width of head/width of body: 0.63 (0.35-0.75); length of individual duct: 93.21 ; length of common duct: 19.12; individual duct/ common duct: 4.88 (4.38-21.57).

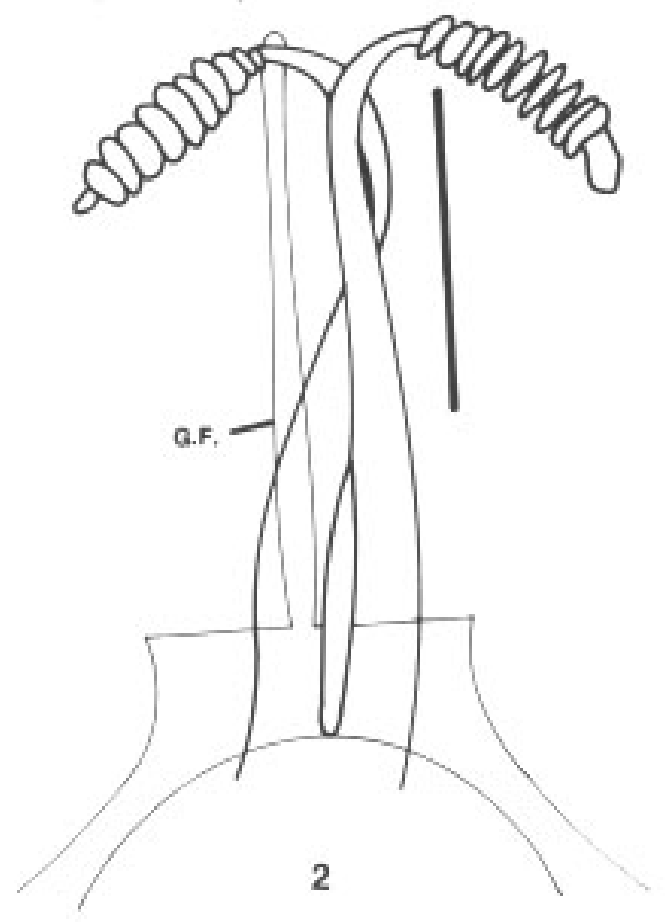

Fig. 2: spermathecae and ducts of Lutzomyia neivai - Fortin Campero, Tarija, Bolivia (BOBE-14F); G. F.: genital fork; bar$40 \mu \mathrm{m}$.

Type-material: the male was collected by $\mathrm{R}$ Fischer in Instituto Butantan, in 2.VII.1926, and is at the Instituto Oswaldo Cruz collection (IOC2267); a female from Fortin Campero, Tarija Department, Southern Bolivia (border of Argentina), was collected by Dr F Le Pont and deposited at Faculdade de Saúde Pública/USP (São Paulo) (DE/ FSP-E-10971); several female specimens, collected under the same conditions, will be deposited at the same institutions as noted for $L$. intermedia.

Known geographical distribution: Bolivia, Argentina (Tucuman and Salta Provinces), Paraguay and Brazil [Goiás, Minas Gerais (in some localities situated west and southwest of Lagoa Santa), São Paulo (in some localities situated in Serra do Mar and the region to the west of Serra do Mar and in Pariqüera Açu), Paraná, Santa Catarina e Rio Grande do Sul].

Observations: heads of spermathecae (122 specimens) were simple (95\%), asymmetric (2.5\%) or bilobated $(2.5 \%)$; the comparison between the ratio width of the head / width of the body in the species is shown in Table I. In 88 examined female specimens, $79(89.8 \%)$ had ten horizontal teeth, $8(9.1 \%)$ had eight and $1(1.14 \%)$ had 12 . A female collected by F. Fonseca in 2.V.1937 in Butantan Institute (code I. B.- 2287) had the following features: spermatheca length-34.42; "head" length- 9.56; "head" simple; 9 rings; individual duct- 72.66; common duct- 20.55.

Besides the type material, several specimens of both species were studied, and measurements with significant differences (ANOVA) are shown on Tables I and II, for females and males, respectively.

\section{DISCUSSION}

Females of $L$. neivai are differentiated from those of $L$. intermedia by the spermathecae, i. e., the total length, the number of rings, the shape and width of the head, absolute and when compared to width of body, the length of their common ducts, absolute and when compared to individual ducts, and the number of cibarial horizontal teeth. Dissection of spermathecae and ducts is useful, but not indispensable, in distinguishing species. Alpha $(\alpha)$ and $\alpha / \beta$, of the wing venation, were significantly greater, in both sexes, in L. neivai, and can be useful in distinguishing the species. The length of spermatheca/ number of cibarial horizontal teeth of cibarium ratio is significantly greater in $L$. intermedia. The size of several structures may help in identification.

Although several structures were different in male L. intermedia and in L. neivai, their ranges overlap and there is a great variation. Other studies are necessary to differentiate the males of both species.

These species are sympatric in Pariqüera Açu, in the State of São Paulo; the females could be distinguished easily (Table III). Other species of the subgenus can be distinguished from both species, using the key of Young and Duncan (1994 - p. 445449).

Specimens from the State of Espírito Santo, mostly those from $750 \mathrm{~m}$ a. s. 1., were larger than the neotype of $L$. intermedia. These variations in the size of $L$. intermedia, possibly related to altitude, were not considered great enough to define different specific categories (Marcondes et al. 1994).

The description and the figures of Forattini (1973, p. 417-419), and the figures of Young and Duncan (1994) probably refer to L. neivai; the key 
TABLE I

Dimensions and proportions in females of Lutzomyia neivai and L. intermedia

\begin{tabular}{|c|c|c|c|c|c|c|}
\hline \multirow[b]{2}{*}{ Structures } & \multicolumn{3}{|c|}{ L. neivai } & \multicolumn{3}{|c|}{ L. intermedia } \\
\hline & Mean & s. d. & $\mathrm{N}$ & Mean & s. d. & $\mathrm{N}$ \\
\hline Horiz. teeth of cibarium ${ }^{b}$ & 10.18 & 0.66 & 87 & 8.22 & 0.62 & 124 \\
\hline Length of labrum $b$ & 348.3 & 21.5 & 131 & 338.7 & 22.2 & 169 \\
\hline A III/ labrum ${ }^{b}$ & 0.645 & 0.05 & 59 & 0.742 & 0.18 & 127 \\
\hline$\alpha^{a}$ & 606.4 & 53.1 & 109 & 581 & 108.5 & 135 \\
\hline$\alpha \beta^{b}$ & 2.23 & 0.35 & 65 & 1.99 & 0.28 & 135 \\
\hline$\beta / \delta^{b}$ & 0.85 & 0.17 & 88 & 0.97 & 0.21 & 134 \\
\hline $\begin{array}{l}\text { Number of rings of } \\
\text { spermathecae }\end{array}$ & 8.87 & 1.12 & 115 & 12.21 & 1.49 & 140 \\
\hline $\begin{array}{l}\text { Total length of } \\
\text { spermathecae }^{b}\end{array}$ & 40.49 & 4.68 & 111 & 54 & 6.55 & 135 \\
\hline $\begin{array}{l}\text { Width of body of } \\
\text { spermathecae }\end{array}$ & 13.39 & 1.78 & 117 & 15.28 & 1.61 & 139 \\
\hline $\begin{array}{l}\text { Width of head of } \\
\text { spermathecae }\end{array}$ & 6.32 & 1.42 & 112 & 11.38 & 2.05 & 137 \\
\hline $\begin{array}{l}\text { Width head sperm./ } \\
\text { width body sperm. }{ }^{b}\end{array}$ & 0.47 & 0.1 & 65 & 0.75 & 0.16 & 135 \\
\hline $\begin{array}{l}\text { Length sperm./ hor. teeth } \\
\text { cibarium }^{b}\end{array}$ & 4.03 & 0.6 & 62 & 6.61 & 0.78 & 115 \\
\hline Length individual duct ${ }^{a}$ & 91.19 & 12.9 & 56 & 84.69 & 18.17 & 74 \\
\hline Length common duct ${ }^{b}$ & 15.03 & 6.34 & 52 & 40.17 & 13.29 & 69 \\
\hline $\begin{array}{l}\text { Length indiv. duct/ } \\
\text { length common duct } b\end{array}$ & 7.55 & 3.33 & 49 & 2.41 & 0.99 & 69 \\
\hline
\end{tabular}

$a$ : significance at $5 \% ; b$ : significance at $1 \%$ or greater; s.d.: standard deviation, N: number examined; $\alpha$ : length of $R_{2}, \beta$ : length of $R_{2+3}, \delta$ : distance between distal extremity of $R_{1}$ and the fork of $R_{2+3}$

TABLE II

Dimensions and proportions in males of Lutzomyia neivai and L. intermedia

\begin{tabular}{|c|c|c|c|c|c|c|}
\hline \multirow[b]{2}{*}{ Structures } & \multicolumn{3}{|c|}{ L. neivai } & \multicolumn{3}{|c|}{ L. intermedia } \\
\hline & Mean & s. d. & $\mathrm{N}$ & Mean & s. d. & $\mathrm{N}$ \\
\hline Length of head ${ }^{a}$ & 335.2 & 14.4 & 159 & 326.6 & 39.3 & 98 \\
\hline$\alpha^{a}$ & 512.4 & 51.9 & 85 & 484.6 & 50.5 & 123 \\
\hline$\beta^{a}$ & 259.7 & 31.9 & 87 & 268.6 & 30 & 126 \\
\hline$\delta^{b}$ & 269.2 & 56.7 & 86 & 245.4 & 47.3 & 122 \\
\hline$\varepsilon^{b}$ & 621.6 & 48 & 85 & 601 & 52.6 & 123 \\
\hline Fork $\mathrm{M}_{1}-\mathrm{M}_{2}$ to $\mathrm{f} . \mathrm{R}_{2}-\mathrm{R}_{3}{ }^{a}$ & 163.2 & 28.8 & 83 & 172.5 & 35 & 119 \\
\hline$\alpha / \beta^{b}$ & 2 & 0.32 & 85 & 1.81 & 0.3 & 124 \\
\hline$\beta /$ length of wing $b$ & 0.14 & 0.02 & 86 & 0.15 & 0.29 & 124 \\
\hline $\mathrm{R}_{5}^{a}$ & 1214 & 60.34 & 50 & 1188 & 79.86 & 100 \\
\hline $\mathrm{R}_{5} /$ length of wing ${ }^{a}$ & 0.67 & 0.03 & 50 & 0.65 & 0.037 & 97 \\
\hline Length of coxite ${ }^{b}$ & 262.7 & 33.53 & 101 & 281.4 & 20.54 & 147 \\
\hline Length of style $\mathrm{e}^{b}$ & 132.4 & 6.55 & 100 & 139.3 & 7.99 & 147 \\
\hline Genital pump ${ }^{a}$ & 194 & 53.6 & 100 & 206 & 15.54 & 147 \\
\hline Genital filaments $^{a}$ & 287.8 & 19.89 & 97 & 298.2 & 31 & 148 \\
\hline Genital filaments/gen. pump $^{a}$ & 1.51 & 0.16 & 97 & 1.46 & 0.13 & 147 \\
\hline $\begin{array}{l}\text { Length pump/ maximal width } \\
\text { pump }^{b}\end{array}$ & 2.94 & 0.32 & 89 & 3.21 & 0.42 & 138 \\
\hline
\end{tabular}

$a$ : significance at $5 \% ; b$ : significance at $1 \%$ or greater; s.d.: standard deviation, N: number examined; $\alpha$ : length of $R_{2}, \beta$ : length of $R_{2+3}$, $\delta$ : distance between distal extremity of $R_{1}$ and the fork of $R_{2+3}$. $\varepsilon$ : length of $R_{3}$. 
TABLE III

Dimensions and proportions in females of sandflies from Pariqüera-Açu (São Paulo). Comparison between first four insects, identified as Lutzomyia intermedia, and other nine, identified as L. neivai

\begin{tabular}{|c|c|c|c|c|c|c|c|}
\hline Sandflies & $\begin{array}{l}\text { Cibarium } \\
\text { horizontal } \\
\text { teeth }^{b}\end{array}$ & $\begin{array}{l}\mathrm{N}^{0} \text { of } \\
\text { sperm. } \\
\text { rings } b\end{array}$ & $\begin{array}{c}\text { Total } \\
\text { length } \\
\text { of } \\
\text { sperm. }\end{array}$ & $\begin{array}{c}\text { Shape } \\
\text { of } \\
\text { sperm. } \\
\text { head }\end{array}$ & $\begin{array}{c}\text { Width } \\
\text { sperm. } \\
\text { body/w. } \\
\text { sperm. } \\
\text { head }^{b}\end{array}$ & $\begin{array}{c}\text { Length } \\
\text { of } \\
\text { head }^{b}\end{array}$ & $\begin{array}{c}\text { Length } \\
\text { of } \\
\text { wing }\end{array}$ \\
\hline PA-11F & 8 & 12 & 56.4 & wide & 0.667 & 390.82 & 2432.5 \\
\hline PA-6FA & 8 & 14 & 54.7 & bilob. & 0.984 & 396.62 & 2332.4 \\
\hline PA-6F & 8 & 11 & 55 & simple & 0.707 & 390 & 2454.7 \\
\hline PA-7F & 8 & 11 and 12 & 55 & bilob. & 0.46 & 384.2 & 2426.9 \\
\hline PA-1F & 10 & 9 & 49 & simple & 0.304 & - & 2312.9 \\
\hline PA-2F & 10 & 9 and 10 & 39.8 & simple & - & 381.3 & 2315.7 \\
\hline PA-3F & 10 & 10 & 44.7 & simple & - & 371.6 & 2151.7 \\
\hline PA-4F & 10 & 9 and 10 & 41.8 & simple & 0.26 & 367.8 & 2224 \\
\hline PA-5F & - & - & 38 & simple & 0.5 & - & 2123.9 \\
\hline PA-7F & 12 & 10 & 49.5 & simple & $0.29-$ & 384.2 & 2404 \\
\hline PA-8AF & - & 8 & - & - & - & 381.3 & 2251.7 \\
\hline PA-8BF & - & - & - & - & - & - & 2168.3 \\
\hline PA-10F & 10 & - & - & simple & - & 371.5 & 2079.4 \\
\hline
\end{tabular}

$a$ : significance at $5 \% ; b$ : significance at $1 \%$.

of Ready and Frahia (1981) would be more suitable to L. intermedia. Ready and Frahia (1981) studied material from Bahia (Ready 1996, pers. commun.). The authors of the other papers did not indicate which specimens were used in the descriptions and illustrations.

Description of both sexes of Phlebotomus mazzai Paterson, 1926 were based only on external characters. This species has been considered as junior synonym of L. intermedia (Barretto 1946, 1947, Martins et al. 1978, Young \& Duncan 1994.). The types of $P$. mazzai could not be examined.

It is important now to undertake new studies to determine which species occur at each locality and to study the possible differences on their biology and vector competence. For example, both occur in Pariqüera Açu municipality, where several studies of the biology of "L. intermedia" were made (e. g., Gomes et al. 1982, 1986).

\section{ACKNOWLEDGEMENTS}

To Drs Ana L Lozovei (UFPR) and Eunice AB Galati (USP), for useful comments during this work, and to the last named for lending many specimens and donating $\mathrm{NC}$ for mounting insects; to the following colleagues who lent or donated material to this study: Alda L Falcão and Reginaldo P Brazil (CP René Rachou), Alfredo CR Azevedo, Gustavo M Aguiar and Sebastião J Oliveira (FIOCRUZ), Aloísio Falqueto (UFES), François Le Pont (IBBA, ORSTOM), José Eduardo Tolezano and Helena Taniguchi (Inst. Adolfo Lutz), Luc Matile (M. Nat. Histoire Naturelle), Maria Helena Oliveira (UFRPE), Oscar D Salomón (Inst. Pesq. Enf. Chagas Fatála
Cháben), Roberto P Moraes (Instituto Butantan), Ueslei Teodoro (Univ. Maringá); to Drs Nataly Souza and Maurício Vilela (FIOCRUZ), and to Dr Marilene de Brito (SUCEN), for help on the collection of insects in Além Paraíba (MG) and São Sebastião (SP); to Dr Ted Taylor (DF/ CFM/UFSC), for revision of the English language.

\section{REFERENCES}

Barretto MP 1946. Sôbre a sinonímia de flebótomos americanos (Diptera: Psychodidae). Primeira nota. Rev Bras Biol 6: 527-536.

Barretto MP 1947. Catálogo dos flebótomos americanos. Arq Zool São Paulo 5: 177-242.

Cerqueira NL 1945. Novo meio para montagem de pequenos insetos em lâminas. Mem Inst Oswaldo Cruz 39: 37-41.

Forattini OP1973 Entomologia médica $4^{o}$ vol.; Psychodidae; Phlebotominae; leishmanioses; bartoneloses. Ed. Edgar Blucher/EDUSP, São Paulo, $\mathrm{x}+658 \mathrm{pp}$.

Gomes AC 1992. Perfil epidemiológico da leishmaniose tegumentar no Brasil. An Bras Dermatol 67: 55-60.

Gomes AC, Rabello EX, Santos JLF, Galati EAB 1982. Aspectos ecológicos da leishmaniose tegumentar americana. 2. Ecótopo artificial como abrigo de Psychodopygus intermedius e observações sobre alimentação e reprodução sob influência de fatores físicos naturais. Rev Saúde Públ 16: 149-159.

Gomes AC, Santos JLF, Galati EAB 1986. Ecological aspects of american cutaneous leishmaniasis. 4. Observations on the endophilic behavior of the sandfly Psychodopygus intermedius in the Ribeira Valley region of the S. Paulo State, Brazil. Rev Saúde Públ 20: 280-287.

Killick-Kendrick R, Tang Y, Killick-Kendrick M, 
Johnson RN, Ngumbi PM, Sang DK, Lawyer PG 1994. Phlebotomine sandflies of Kenya (Diptera: Psychodidae): III. The identification and distribution of species of the subgenus Larroussius. Ann Trop Med Parasitol 88: 183-196.

Lutz A, Neiva A 1912. Contribuição para o conhecimento das espécies do gênero Phlebotomus existentes no Brasil. Mem Inst Oswaldo Cruz 4: 84-95.

Marcondes CB, Falqueto A, Lozovei AL 1994. Estudo morfométrico de Lutzomyia intermedia Lutz \& Neiva, 1912 de duas localidades em altitudes diferentes no Estado do Espírito Santo, Brasil (Diptera, Psychodidae). Rev Patol Trop 23: 297.

Martins AV, Williams P, Falcão AL 1978. American sand flies. Acad. Bras. Ciências, Rio de Janeiro, 195 pp.

Nitzulescu V 1930. Contribution a l'étude de la femelle du Phlebotomus intermedius. Ann Parasitol 8:523529.

Paterson GC 1926. Sobre otra nueva espécie del genero Phlebotomus encontrada en la Provincia de Jujuy. Bol Inst Clin Quir 2: 305-309.

Pinto C 1926. Phlebotomus neivai e Phlebotomus fischeri n. sp.- sobre o aparelho espiracular dos phlebótomos e seu valor específico. Ciência Méd 4: 370-375.
Rangel EF, Azevedo ACR, Andrade CA, Souza NA, Wermelinger ED 1990. Studies on sandfly fauna (Diptera:Psychodidae) in a foci of cutaneous leishmaniasis in Mesquita. Rio de Janeiro State. Brazil. Mem Inst Oswaldo Cruz 85: 39-45.

Rangel EF, Souza NA, Wermelinger ED, Barbosa AF 1984. Infecção natural de Lutzomyia intermedia Lutz \& Neiva. 1912 em área endêmica de leishmaniose tegumentar no Estado do Rio de Janeiro. Mem Inst Oswaldo Cruz 79: 395-396.

Ready PD, Frahia H 1981. Brazilian Phlebotomines. VI. Lutzomyia richardwardi sp. n., a new species from Nyssomyia from Amazonia with keys for this subgenus (Diptera, Psychodidae). Rev bras Biol 41: 705-712.

Theodor O 1931 Sobre sistemática de los flebótomos sudamericanos. $7^{\text {a }}$ Reunión Soc. Arg. Patol. Reg. Norte, Tucuman. p. 764-786.

Theodor O 1932. On the structure of the buccal cavity, pharynx and spermatheca in South American Phlebotomus. Bull Ent Res 23: 17-23.

Young DG, Duncan MA 1994. Guide to the identification and geographic distribution of Lutzomyia sand flies in Mexico, the West Indies, Central and South America (Diptera: Psychodidae). Memoirs Am Ent Inst, Gainesville. No.54: p. 881. 